\title{
Multilingualism and Multiculturalism in the Education System and Society of Botswana
}

\author{
Eureka Mokibelo \\ University of Botswana, Gaborone, Botswana
}

\begin{abstract}
This study sought to examine how Botswana recognized and celebrated her linguistic and cultural diversity in society and in the education system. At various national celebrations, such as President's Day, National Cultural Day, and National Language Day, Botswana celebrated her linguistic and cultural diversity by inviting ethnic groups from almost all regions of the society to perform cultural dances, poetry, and music while the same dispensation was denied primary school learners from ethnic minority groups. The use of Setswana as the medium of instruction leaves out the learners' cultures, languages, and identities. Teachers and school management were the key participants in the study while learners' artefacts were examined. Data were collected through open-ended questionnaires and interviews and analysis of documents/programmes from the Ministry of Sports, Youth and Culture responsible for national celebrations. The findings indicated that learners were denied linguistic and cultural diversity of their languages and cultures in the classrooms while there was evidence of celebrating culture and linguistic diversity in society. This called for a change in perspective and attitude to extend linguistic and cultural diversity to the classrooms so that learners could become capable of shouldering responsibility of their lives and participate in the development of their country.
\end{abstract}

Keywords: multilingualism, multiculturalism, ethnic minority groups, national celebrations

\section{Introduction}

Even though most African countries are linguistically and culturally diverse, they lack a model of how to face such complexity in the classrooms. The system they adopt is that of assimilating the minority languages and cultures into recognized major or national ones. The problem with assimilation is that its chances of success are limited even if one is prepared to pay a very high price to pursue it (Kukathas, 2004). However, not all cultural minorities want to assimilate to the degree sought by the makers of the social policy. Many resist attempts to assimilate and this may lead to separatist tendencies and resistance which could lead to hardening of attitudes on all sides (Kukathas, 2004). The basic assumption is that the country should have a common language and culture as a basis for political unity and identity supported by the assimilation theory of the "melting pot". In Western countries, the belief was that they needed strong assimilation policy to achieve a common national identity (Gordon, 1964). The dominant language and culture were strongly imposed on ethnic minority groups and their descendents.

The term "multilingualism" can refer to individuals or to societies. Skutnabb-Kangas (2000) defined a multilingual speaker in terms of a combination of linguistic identification, varying skill levels, and capacity to

Eureka Mokibelo, Ph.D. candidate, senior lecturer, Communication and Study Skills Unit, University of Botswana. 
function in at least two languages. Therefore, for this paper, the term operationally refers to a situation where there are a number of languages or linguistic variations in a given community and or in a school. Also, this paper considers that speakers and learners who live within the same community could become multilingual consequent to learning different languages spoken in their community. On the other hand, multiculturalism promotes, protects, and preserves the traditional cultures of learners and the society. It values cultural differences and seeks to maintain it in ways that are not on the interest of individuals (Feinberg, 1996).

Culture is embedded in language; this explains why this paper discusses multilingualism and multiculturalism simultaneously to basically refer to related concepts. This paper regards multilingualism as a situation where different languages are spoken in a community and therefore learners who come from that community would form a heterogeneous class. Learners could speak other languages of the community fluently and therefore be multilingual because there is close interaction between members of different ethnic groups. Because these learners speak different home languages within the same community, they have different cultures because the ethnic groups within their community are different. Therefore, this paper regards such learners as multilingual and at the same time multicultural in that respect.

This paper argues that multilingualism and multiculturalism are ignored in the education system and primary school classrooms of Botswana but recognized and celebrated in society and communities of Botswana. The task of educating children becomes much more difficult when teachers have to face a heterogeneous class with multilingual and multicultural background. Learners bring with them their home languages and cultures that are usually unknown to teachers. This means that both teachers and learners live in worlds that are apart.

This study is important in that it could be an eye-opener to the educational authorities who seem to be overlooking the multilingualism and multiculturalism that exist in classrooms while recognizing it outside classrooms.

\section{Background}

Botswana is located in the Southern Africa, landlocked, and it shares borders with Zambia, Zimbabwe, South Africa, and Namibia, as shown in Figure 1.

Figure 1 also shows the nine regions in Botswana where in some of the regions studied, such as Kweneng, Kgalagadi, Ngamiland, Central, South East, and North East; where different home languages are spoken that are different from Setswana. In most cases, the children go to school speaking only the home languages and start learning the national language at school for the first time. The population of Botswana is currently 2,024,904 (Republic of Botswana, 2011). Botswana's languages are estimated to be around 28 (Batibo, 2005). The number of estimated languages spoken in the country makes Botswana a multilingual state.

At Botswana's independence, there was no clear language-in-education policy in schools. English dominated in the teaching and learning process while Setswana was used at lower levels of primary (Mokgwathi, 2011). Setswana was accepted as the medium of instruction for the first two to three years at primary school level while transition to English varied according to the language competence of the teacher (Molosiwa, 2005). Although English was supposedly the language used for teaching and learning after grade three, this was more of theory than practice because teachers were allowed to code-switch between Setswana and English at lower grades to facilitate students understanding (National Commission on Education, 1977). It was not uncommon to find Setswana being used as a medium of instruction in Standard 7 (Republic of Botswana, 1993). Even indigenous languages in various parts of the country where Setswana was not a home 
language of the majority of learners were used (Molosiwa, 2005). In the North East district, for instance, Ikalanga was used and continues to be used as an informal medium of instruction (Mokgwathi, 2011).

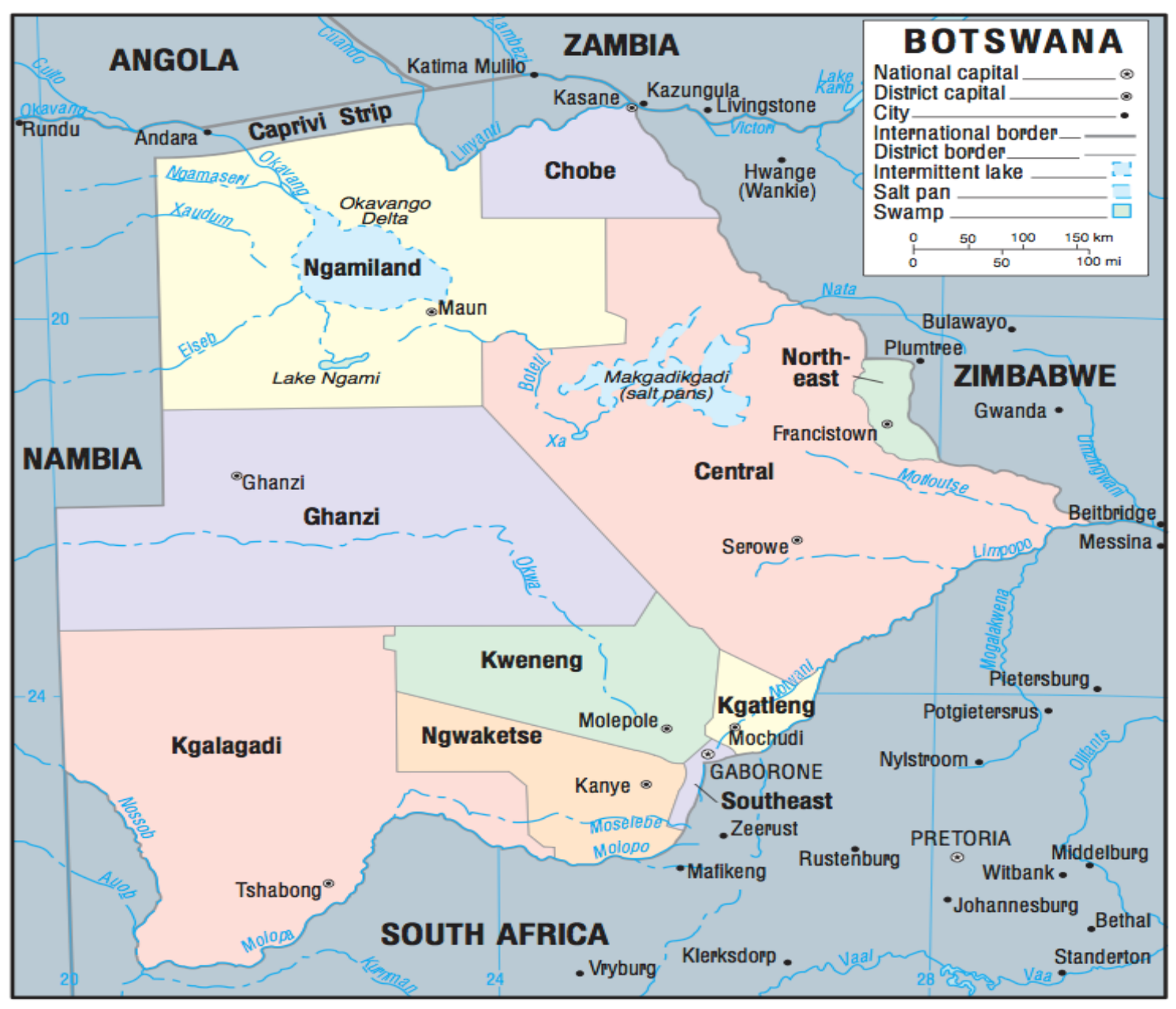

\section{Administrative Districts}

Figure 1. Map of Botswana.

In 1977, a task force named the National Commission on Education was appointed by the Botswana government to conduct a review of Botswana's education system. The commission's recommendations promoted the status of Setswana and be given priority in the education system. Setswana was used as a medium of instruction from Standard 1 to 4 while English takes over in Standard 5 and subsequent levels (National Commission on Education, 1977). The commission was silent on the role of other languages children speak in their homes. In a multilingual country, such as Botswana, a resolution such as this creates inequalities and learning barriers for non-Setswana speakers.

Scholars later revealed problems on the above policy. For example, Arthur (1997) revealed that teachers argued that Setswana was lacking in many ways. Teachers complained that learners started using English as a medium of instruction late at Standard 5 (Arthur, 1997). Secondly, there were communication problems in the classrooms where learners speak different home languages from Setswana. Further, he pointed out that teachers who were not first language speakers of Setswana had a problem teaching in Setswana. Nyati-Ramahobo (1999) 
investigated the implementation of the language policy in Botswana in the education system, society, and government sectors and found that Setswana language, though identified and used for national identity and unity, is not a resource in the classrooms, instead, it becomes a problem because of the language. She found out that there was a dislocation between policy formulation and policy practice. Again, it was observed that since English is the language of examinations, learners were not proficient in the language by the time they write their Primary School Leaving Examinations (Republic of Botswana, 1994).

The government set up another commission to review the entire education system in 1991 and this commission came up with a report known as the Revised National Policy on Education in 1993. The arguments and decisions of the commission were based on the experiences of those countries which de-emphasized the use of English as the medium of instruction in their education systems. Such countries as Tanzania and Malaysia realized the limitations of not emphasizing English in their business relations with other countries in the international economy (Republic of Botswana, 1993). Also, the commission noted that countries, such as Japan and South Korea, are beginning to emphasize English in their education system in recognition of its importance as the main language of business.

In Botswana's effort to industrialize and attract foreign investment, English will continue to play a major role in business (Republic of Botswana, 1993). Hence, the languages of instruction were given a new and different status at primary school level. The Government Paper No. 2 of 1994 (Republic of Botswana, 1994) changed the positions of English and Setswana. It recommended that Setswana be used as a language of instruction at Standard 1 while English is taught as a subject. At Standard 2, English becomes the medium of instruction and Setswana is taught as a subject. This latest change forms the basis of investigation of this study. This study argues that all the phases of change that the language-in-education policy has gone through seem to neither have improved proficiency in English nor raised the status of Setswana and use it as a unifying factor. Instead, the shifts have managed to widen the gaps that exist between the major and minority language groups of Botswana (Chebanne, 2002). Also, the gaps indicated still undermine the multilingual society Botswana is.

The policy recommends that "English should be used as the medium of instruction from Standard 2 as soon as practicable" (Republic of Botswana, 1994, p. 59). The recommendation to use English was reached after considering that learners do not get enough exposure and experience in English and yet they are required to write their examinations in the language. It was felt that using English as the medium of instruction from Standard 2 will improve their performance.

In brief, the current language-in-education policy states that at Standard 1, Setswana is used as a language of instruction while English is taught as a subject. At Standard 2, English becomes the language of instruction while Setswana is taught as a subject. This shows that Botswana has always retained two languages of instruction, Setswana and English, in the education system since independence in 1966. The implications of all these policies are that Botswana is a monolingual society and therefore only Setswana shall be used as the medium of instruction at standard lower primary. Other minority languages are not important and therefore the speakers of other languages shall continue suffering by learning in an unfamiliar language. The other assumption is that Botswana classrooms are homogenous and therefore the use of Setswana suits all student population. In reality, the policy has been disadvantaging children who come to school speaking different home languages from Setswana. 


\section{Theoretical Framework}

Kymlicka's (1995) theory of multicultural citizenship was chosen to explain the situation and aspirations of ethnic minority groups in Botswana education system. This theory argues that indigenous people are considered among the world's most disadvantaged groups and belong to the most vulnerable and impoverished segments of societies in virtually all of the states they are found in. The reasons vary for such characteristics. First, their exclusion from the decision-making process, their small numbers of members, their great cultural distance to the majority groups, their geographical isolation, their fragile ecology, and also their ways of living that tend to be different with modernity. In most cases, governments adopt policies that seem to reverse their lives to suit that of the major groups; for example, the idea was to assimilate them into the mainstream society. It is in isolated cases where ethnic minorities stand up for their land rights, cultural rights, and self-government rights needed to perpetuate themselves as distinct groups. Secondly, the theory articulates that the ethnic minorities are associated with poverty reduction. Ethnic minorities quite often represent poor people who are left behind (United Nations Development Program (UNDP), 2003).

\section{Methodology}

This study was conducted in 2012 in six primary schools in different regions of Botswana, but only four primary schools with similar characteristics shall be used for this paper. The study used the qualitative approach with classroom observations, interviews, open-ended questionnaires, and field notes to collect data. The main aim of the study was to observe how a policy that recognized only English and Setswana in such a multilingual and multicultural society is implemented in situations where learners go to school speaking only the home languages and where there are foreigners and immigrants. Classes observed were characterized by the following:

(a) Otjiherero $=40 \%$, Shekgalagari $=30 \%$, San languages $=20 \%$, and Setswana $=10 \%$;

(b) Khoekhoegowab $=10 \%$, Nama $=10 \%$, Shekgalagari $=10 \%$, Afrikaans $=20 \%$, Setlhware $=30 \%$, Shengologa $=10 \%$, and Otjiherero $=10 \%$;

(c) San languages $=50 \%$, Shekagalagari $=20 \%$, Shebolooongwa $=10 \%$, Seshaga $=10 \%$, and pigeon of Setswana and Shekgalagari $=10 \%$;

(d) Foreign languages $=20 \%$, Setswana $=60 \%$, Ikalanga $=8 \%$, Shiyeyi $=5 \%$, Shekgalagari $=5 \%$, and other languages $=2 \%$.

For this paper, the researcher used Standard 1 classes where the language of instruction was Setswana for the whole student population despite their ethnic and linguistic diversity. Therefore, depending on the size of the school, nine Standard 1 classes were used to justify the problem being discussed. Twelve Standard 2 classes were observed to see how learners are coping with the switch to English after learning Setswana for only one year calendar. Six Standard 4 were also observed, because learners write attainment tests; hence, the idea was to see whether learners cope with the two languages of instruction that they learn as a second, third, or fourth language. Eight Standard 7 were also observed, because this is where learners write Primary School Leaving Examinations. The idea was also to see whether at this stage learners are ready to write examinations to see whether they have acquired the basic language skills to help them in writing the final examinations. A total of 36 classes were observed. The schools referred to in this study are four rural primary schools where learners go to school with different home languages and in most cases hear the languages of instruction at school. The data 
were analyzed according to thematic statements in line with the key research questions. The issue of multilingualism and multiculturalism emerged as a subtheme from the observations in the classrooms.

The justification for multilingualism and multiculturalism awareness was from documents from the Ministry of Youth, Sport and Culture where different events were celebrated nationally or at community level to showcase that indeed Botswana was multilingual and multicultural.

\section{Results From Observations: Botswana Education System}

\section{The Language-in-Education Policies}

The Botswana language-in-education policy recognized only two languages of instruction from before and after independence despite the fact that there are other 28 languages. This situation has not been changed although there have been shifts in the policy. The position of Setswana has been shifting from using it as a language of instruction for three, four, and one year only at the initial stages of learning. None of the indigenous languages has been used. However, research from this study indicates that teachers and school management informally use mother tongues for certain ethnic groups while leaving out the others. This is an unplanned phenomenon that is done haphazardly. Importantly, the informal use of the languages of instruction indicate that indeed Botswana is multilingual and this needs to be strongly acknowledged and recognized in the classrooms.

The results of the classroom revealed that:

1. Teachers are aware that the classes are heterogeneous and/or multilingual but this is ignored in the classrooms;

2. The learners' culture is ignored, only the teacher's culture or the culture in the curriculum is imposed on the learners;

3. Teachers and learners do not share a common language, because teachers come from a different background from that of the learners;

4. Learners are silent in the classrooms and participation is minimal because learners' culture and language are not used in the classrooms, they are learning with an unfamiliar language;

5. Learners drop out of school as early as Standard 1, because the knowledge they bring from home is not used and ignored in the classrooms;

6. Teachers do not provide opportunities enough to dig out the potential from learners' different cultures.

The findings of this study indicates that some of the voices of the teachers from rural primary schools were as follows:

I do not speak the same language as learners and therefore it is very difficult to teach them.

I come from Kgatleng, I only speak Sekgatla (Setswana dialect) and English, my students speak Otjiherero, San languages, and Shekgalagari, and I do not speak the languages.

I am teaching these children by the grace of God, it is difficult to reach them, because we come from different backgrounds.

These quotations suggest that classes are heterogeneous; learners and teachers do not share a common language; and learners and teachers do not share a common culture and therefore this situation does not give room to share ideas, experiences, and cultures because of different historical backgrounds.

The findings from some of the schools that are heterogeneous in rural areas indicate poor academic 
performance and the teachers and school management attribute such results to the languages of instruction that are exclusive. The results indicate a consistent range from $23 \%-35 \%$ in rural primary schools. The teachers link the poor performance to languages of instruction because they argue that learners fail to follow instructions in the examinations because they do not understand them. Some copy the instructions many times to fill up the pages they are supposed to answer probably because they do not understand what they are supposed to do. Others write the examinations having given up that they will not pass and in the end they do not perform well. Lastly, the teachers argue that learners misinterpret the examination instructions and do things they are not supposed to do because they do not understand what the instruction wants.

The other indirect consequence mentioned by school management for lack of multilingualism and multiculturalism in the classrooms is indicated by the high school dropout at lower primary school. The school management records 20-25 dropouts in Standard 1 and 2 classes where the two languages of instruction are used. The reasons teachers advance for such a high dropout is that learners do not understand the languages of instruction used in Standard 1 and 2 classes, hence, they find no reason to sit in the classrooms while they cannot benefit. The learners find the languages difficult and therefore limit their expressions to share ideas and experiences. In this regard, the learners resort to staying away from school. However, the high school dropout in Standard 1 and 2 classes is a cause for concern. It should be considered that both the parents and learners decided that their children need to go to school, but the school is disappointing them, because it does not recognize who they are. Language is used as power in this regard.

\section{National Events}

The paper also uses some extracts from speeches prepared for celebrating cultural and language days in Botswana by the Ministry of Sports, Youth and Culture and Botswana shows that indeed Botswana acknowledges that it is multilingual and multicultural. Some of the celebrations done are independence holidays, language days, and cultural days. These are Babirwa Dance, Kuru Dance, Domboshaba Cultural Day, President's Day, National Language Day, Phatisi, Segaba, Polka, Setinkane, Seperu, Tsustsube, Setapa, Ngwao Lošalaba, to name a few. Not all these cultural activities will be discussed in this paper because some of them perform under events, such as the President's Day celebrations.

President's Day celebrations. Botswana celebrates President's Day competitions by calling groups to showcase and promote Botswana's visual and performing arts presented in diverse languages as well as talent of the local communities. The ethnic groups are awarded prices in terms of money. The groups are from Central, Ngamiland, Chobe, Kweneng, Ghanzi, North East, North West, and Kgalagadi. These regions are characterized by different ethnic groups and therefore the regions display/demonstrate their different cultural dances, music, and poetry, such as Tsutsube, Seperu, Sebirwa, Diware, Hosanna, Setapa, Phathisi, Polka, Segaba, Setinkane, and Katara. The government spends a lot of money to transport these groups from their regions and feed them as well to come and celebrate the independence holidays.

National Languages Day. The language day is also celebrated in February of every year, a month that was declared by United Nations General Assembly under the theme that Languages Matter. The Ministry of Sports, Youth and Culture shifts the places of celebrations to various areas for commemoration of this day. The main purpose of the theme is to sensitize the public on the several local languages spoken in Botswana, which bear testimony to rich diverse cultures of Botswana. On this day, there are a number of activities done, such as display of greetings in different languages of Botswana. 
Constituency art competitions. This cultural practice is done to celebrate cultural practices and artistic expressions to recognize local languages. The celebrated categories comprise of drama, traditional songs and dance, and traditional musical instruments and choirs which are held at the ward and constituency levels, to bear testimony to the promotion of local languages. The different musical groups come in their different attires and sing songs based on events that are happening in the community and nationally. In some cases, these choirs have patrons who support them when they want to go and sing for a particular event or want to share their songs with other groups.

Kuru Dance Festival. This type of festival was initially meant for San groups in various regions of the country, however, it was modified to include other ethnic groups and institutions. The ethnic groups come from Ghanzi and surrounding areas, Baherero from Namibia, Chobe, and Ngamiland, Bayeyi from Chobe, San from Namibia, and University of Botswana traditional dance group. The groups showcase their cultures in songs, dramatize their songs and cultural events. Different cultural musical instruments are used to support the dances and music. On this day, an interpreter who is multilingual is appointed as the master of ceremony to try and reach most of the groups that are involved in the festival. Again, the festival is attended by ministers, members of parliament, councilors, chiefs, and sponsors from various parastatals and organizations.

National cultural events. In Botswana, various communities host annual cultural festivals, such as Domboshaba, Mbungu wa Kathima, Otjiserandu, Lentswe la Batswapong, Reteng Coalition of Multicultural Groups, Seigochwe Festival, Bakgatla Heritage month celebrations, Dikgafela tsa Bakgatla ba ga Mmanaana, and Otjingirine and Basubiya Cultural Festival. These various groups from different regions of Botswana showcase their culture and talents annually in their communities. The events are characterized by traditional dances of each ethnic group, brewing traditional bear, display of their totems, traditional attire, traditional schools of Bogwera le Bojale, especially Balete and Bakgatla, display of what the communities have harvested. Critical to the celebrations is that they are done in the ethnic groups languages, the music and poetry are in their languages to indicate their cultural identity and unity within the community. These celebrations are usually attended by officials from various ministries, chiefs, members of parliament, and councilors.

In essence, Botswana is very much aware that she is multicultural and multilingual and makes all the efforts to acknowledge this diversity by involving various organizations and parastatals to sponsor the cultural and multilingual events. It also observes the days set aside by international organizations, such as United Nations to celebrate language days. Also, government authorities and village leaders attend these celebrations where most of them are guest speakers or honorable guests.

\section{Discussion of Findings}

\section{Multilingualism and Multiculturalism Awareness}

It is clear from the various national celebrations that authorities are aware that Botswana is multilingual and multicultural and hence they support and promote the status in various communities of Botswana. The fact that these celebrations are graced by top authorities in Botswana and outside and they present speeches, it is an indication that indeed the authorities would like to encourage Batswana to keep, preserve, and maintain the spirit of multilingualism and multiculturalism. For example, when commemorating the National Languages Day, the then minister of Sports, Youth and Culture stated that "Botswana is endowed with rich diverse cultures, such as our languages, cultural practices and traditions, which if fully exploited can significantly 
contribute to the socio economic development strategies for our people" (Republic of Botswana, 2013). While this is celebrated in communities, the same is not extended to classrooms. Children from various ethnic groups in the classrooms who speak different home languages from the national language suffer silently, because they do not have the Setswana vocabulary to express themselves. For example, it was a common phenomenon in most rural classrooms to find lack of participation, silence, confusion when doing practical work, lack of following instruction, and poor academic performance. Actually, the primary school leaving results for Standard 7's percentage ranged from 23\%-35\%. This low percentage could be linked to the characteristics found in such classrooms that no effective learning is taking place due to lack of recognition of heterogeneous classes. Bule (2015) argued that a good mastery of a language enables a person to use idioms, proverbs, and other forms of speech which are critical to an artiste when composing a song, for example, symbolisms are also very important to the artiste. The same argument can be extended to the language a learner uses in the classroom.

The National Cultural Day was celebrated in Goodhope in 2012. The speaker posited that "The main aim behind the decade is to remind nations of the role that culture plays in the socio-economic development and everyday lives of the people" (Republic of Botswana, 2012). Whereas the issue of culture is celebrated and emphasized here, children are denied their cultures in the classrooms, the curriculum and the teaching and learning process denies them to explore their cultures, because there is no language to express it. For example, teachers in rural primary schools confessed that they come from different backgrounds with learners, and therefore, do not share the same historical background. In this regard, it is possible that learners' cultures will be ignored in the teaching and learning process, as Kymlicka (1995) pointed out that lack of multilingualism and multiculturalism excludes learners from participating in their countries development.

How the President's Day is celebrated is another way of acknowledging that Botswana is multilingual and multicultural, because performers are requested to showcase their cultures in their languages. Then, they are awarded prices by the president to acknowledge such diversity. For example, some of the awards were as such in 2013 (Republic of Botswana, 2013, pp. 12-13):

(a) Nandauve Seperu Group—P22,500.00;

(b) Kamberea Cultural Group-P25,000.00;

(c) Matsosa Ngwao Cultural Group-P25,000.00;

(d) Tjilinje Che Ngwao-P22,000.00;

(e) Zauzera Cultural Group-P22,500.00;

(f) Kalahari Dancers-P17,500.00.

The names given to the cultural groups above indicate that the performers are from different ethnic groups, because the names reflect the languages they speak since they use their languages to showcase their performances, whether the audience understand what they say or not is not important. The lucrative awards also indicate that indeed the president in very much supportive of multiculturalism and multilingualism and even asking them to keep on improving so that following year the performances are better.

However, there is no evidence from the classrooms to indicate that at least the authorities are concerned by the fact that multilingualism and multiculturalism exists in the classrooms, because it is not celebrated. Instead, learners are not using their languages and cultures and this affects learners negatively academically. In the four rural primary schools studied, there was an outcry of communication problems and interventional strategies 
were sought to address such communication problems. For example, in three of the schools, cooks, cleaners, teacher aides, and learners' services were sought to interpret and translate instructions to the learners. The involvement of such services proved to be futile, because the people who were called in to assist had other duties in school to perform. Also, the exercise was found to be time-consuming, because such services were not provided when they were needed. Hence, in their absence, there was no effective teaching and learning taking place. It needs concerted effort like it is done in celebrations to alleviate the communication problems. Instead, the multilingualism situation is seen as a problem and a threat to unity (Nyati-Ramahobo, 1999; 2000). Although this has been a long standing problem for decades as indicated by researchers (Le Roux, 1999; Nyati-Ramahobo, 1999; Hays, 2002; Chebanne, 2002; Polelo, 2004; Pansiri, 2008; Bolaane \& Saugestad, 2006) it is not rendered an urgent matter.

\section{The Monolingual Status}

Looking at the previous and current Botswana language-in-education policies, only one national language, Setswana, has been enjoying the second status from English. Setswana has been shifted from being used for the first three years, four years, and currently first year of primary schooling. The emphasis of this being that learners should start learning in their "first language" (Republic of Botswana, 2005). This is a misconception and therefore the place of Setswana as a language of instruction at different levels has always disadvantaged learners who speak different home languages from Setswana as their first languages and this denies learners to explore their true identities and potential. The policies have been silent about the indigenous languages and cultures that exist in the classrooms. Although in other regions, such as the North East, before independence, learners were taught in Ikalanga, this was stopped after independence because it was seen as a threat to national unity and Setswana language was prescribed (Nkosana, 2009; Mokgwathi, 2011). The fact of the matter is that Botswana is not a monolingual country, at least 28 languages exist (Batibo, 2005). The prescription was based on the fact that all Batswana speak Setswana as a first language. This prescription is like asking everyone to be the same height, same weight, or wear same shoe sizes whereas everyone, societies, and communities are unique and have different languages and cultures that they identify themselves with. The decision to view Botswana as monolingual has excluded the ethnic minority groups (Kymlicka, 1995). Pai (2005, p. 1796) pointed out a common phenomenon amongst ethnic minority children that in Mumbai, children are exposed to at least four languages in their neighbourhood and they learn to use them. This could be a problem in school setting, because instruction in school is imparted in the standard variety, while language learnt in neighbourhood may be a dialect or it may not provide adequate exposure, resulting in speech habits that are not acceptable for school purposes. The same situation is relevant to learners in Botswana; they could be learning Setswana as a third or fourth language because of their exposure to different languages spoken by other ethnic groups in the same community.

Looking at how Botswana celebrates its multilingualism and multiculturalism, ethnic groups are not asked to perform one Setswana song; they are allowed to showcase different songs and performances, in different languages and cultures of their regions. In this case, indigenous languages and cultures are allowed in the amphitheatre but not in the classrooms. Languages and cultures are not imposed on other groups and arguably the groups do their best in whatever pieces of performance they showcase, because they are allowed to perform in the languages they know and understand best. Languages that go along with their emotions and heal them one way or the other are used. In support of mother tongue education, Wolff (2010) argued that by clipping the 
learners' mother tongue competence and thereby, impeding the natural development of their cognitive and intellectual potential, they have gained no linguistic, practical, and intellectual skills that would allow them to become better farmers, gardeners, herdsmen, craftsmen, etc.. Tötemeyer (2009) argued that the benefits of using learners' mother tongue or first language are that children attend school regularly; learners do not drop out easily, they are academically more successful and learn a second language more easily.

\section{Mismatch Between Policy Intentions and the Realities of the Classrooms}

The current research indicates the fact that Botswana language-in-education policy does not recognize the linguistic diversity that exists in the classrooms; this does not favor ethnic minority learners who do not speak the target languages. The findings from the study indicate that the ethnic minority classrooms are characterized by silence, lack of participation, teacher dominance, and boredom, which indicates that their languages are valueless in the classrooms, their languages are not allowed in the classrooms, and therefore they are rendered weak because they cannot share their ideas orally and in writing. This does not come as a surprise. Scholars believe that strong academic and conceptual skills in the mother tongue are crucial for achieving good skills in an additional language. The intellectual and academic resources of bilingual learners could also increase if the first language is maintained (Cummins, 2000). Also, Skutnabb-Kangas $(1988 ; 2000)$ argued that it is the responsibility of the state to provide an education system where multilingualism is treated as a necessity. All children in a country should be given the same opportunity to participate and become active citizens, regardless of whether or not their mother tongue differs from the official language(s). In one of Botswana local newspaper Botswana Guardian Northern Extra articles entitled "Cultural Festivals Prioritised Over Mother Tongue Teaching", the writer Edward Bule pointed out that government promotes cultural festivals such that it sponsors them, however, Bule (2015) acknowledged the fact that government has argued that teaching the other local languages besides Setswana would be costly. Government used the absence of teachers and books in the indigenous languages as defence in its reluctance to teach the indigenous spoken in this country. The writer argued that "Observers say it is both contradictory and hypocritical to deny the so-called minority tribes the opportunity to learn their languages at school and then turn around and sponsor the preservation of their cultures" (Bule, 2015, iii). The government has adopted a policy that seems to reverse the lives of ethnic minority learners to suit that of the major groups (Kymlicka, 1995).

The behavior observed on what happens in the national celebrations in society is that the audience and performers are happy, ululate at different performers and performances, laugh and enjoy the celebrations while some wish that they could not even cease on that particular day. The winners are awarded prizes while in the classrooms, learners are not rewarded or awarded any prizes because of being taught in their weaker languages - something they did not chose. People gather together in celebrations to come and witness the performances and witness the award-winning groups and they come from different parts of the country and even neighbouring countries. The same behavior is not happening in the ethnic minority classrooms, because they do not win in the end, instead, they run away from the very place where they could be enjoying their learning. Only the researchers are making noise about the missing children and the high school dropouts (see Le Roux, 1999; Hays, 2002; Polelo, 2004; Nguluka \& Gunnestad, 2011; Mokibelo, 2014) and are concerned about how the learners could be retained in school. Also in Mumbai, authors found that there was a heavy dropout rate among the children of the fishermen community by the time they reached secondary school due to learning in an unfamiliar language (Pai, 2005). 


\section{Colonizing and Decolonizing the Ethnic Minorities}

Although colonization in Botswana ended before independence, it still exists today where ethnic minority groups are concerned in the education system. The colonizers imposed their languages on their people; hence, English, French, and Portuguese dominate in the countries that were colonized by Britain, France, and Portugal. Today, the colonizers have left, and now it is the education system that is colonizing students with the national language. For example, instead of promoting linguistic and cultural diversity, the education system is assimilating non-Setswana speaking groups into Setswana culture with Setswana language. Setswana is not a first language to all Batswana, and the education system is forcing all the student population despite the linguistic diversity into speaking the language for the sake of unity and identity. This is similar to colonization and its assimilation strategies. Again, the colonizers' languages opened doors for learners in terms of jobs and further education and if learners did not acquire the language, in most cases, they were left out towards the development and growth of their countries. This is what the education system is doing with Setswana in the lower rural primary schools. Learners fail to acquire the target language and they decide to drop out of school because they find no reason to sit in the classrooms when they are not benefiting from the education system.

On the other hand, the authorities are decolonizing the people of Botswana outside the classrooms by entertainment celebrations. The authorities are telling Batswana that their languages are important and their cultures are nurtured so that they should not die. The authorities pay and support Batswana performances in kind and financially while in the classrooms, the education system is doing the opposite. Performers are allowed to showcase their identity and take pride in their cultures and languages. In fact, the festivals and celebrations bring the various groups together as Batswana and yet in the classrooms, learners are being driven out of the classrooms by lack of linguistic and cultural diversity. It has been proven beyond reasonable doubt through evidence from the classrooms that Setswana is driving learners away from education generally at the initial stages of learning (Le Roux, 1999; Polelo, 2004; Pansiri, 2008).

\section{Persistent Inequalities}

Lack of recognition of multilingualism and multiculturalism in the classrooms present inequalities in the education system and beyond (Hays, 2002; Chebanne, 2002). For example, the findings indicate that firstly, learners who speak Setswana as a first language benefit from learning, because they understand the language of instruction while their counterparts who learn it as a second, third, or fourth language do not understand it; secondly, there are communication problems between the teachers and learners, because in most cases, teachers speak Setswana as a first or second language while on the other hand, ethnic minority learners hear Setswana for the first time at school. Teachers who speak different home languages from the learners' languages are posted to their schools and there is evidence of communication breakdown (Arthur, 1997). Setswana-speaking learners enjoy learning and succeed in school while ethnic minority learners drop out in large numbers at lower grades, because they find no reason to sit in the four walls of the classrooms while they are struggling with the content and the language. Also, learners from the ethnic minority groups do not receive the same education, because they cannot even access it due to the language problem while their Setswana-speaking counterparts have access to information and knowledge in their first language. Again, it is a fact that ethnic minority learners drop out of school early, they do not enjoy the economy of the country, because they are pushed away in rural areas where there are no jobs. Further, these learners cannot participate in the economic, academic, social, and political aspects of the country because of their languages while their Setswana-speaking counterparts proceed 
to tertiary education and beyond. This is a pathetic situation that needs to be addressed especially in the spirit of democracy.

Looking at the celebrations, the majority of groups that participate are the ethnic minorities coming from various regions to the capital city of Gaborone. They are offered equal opportunity to participate and win. They are allowed to sing in their different languages and not Setswana and that is why the groups outperform and win! They win big prizes because they have been given an opportunity to showcase their potential and talent in their own context and language. Further, the Kuru Dance in Ghanzi region, the San, and other ethnic groups are allowed to showcase their talents and potential in their languages. Audience come from far regions to watch the performances by San communities and other ethnic minority groups, whether people understand the languages or not, they still enjoy the rhythms, drumming, and songs and take pictures of the performances. Can a volunteer just visit one school attended by ethnic minority learners and take pictures of learners being silent, not participating, looking bored and show them to the authorities to take action and change the situation in the classrooms? Things being equal, this problem could be a concern for every citizen, not to want to use ethnic minority people for entertainment and turn their backs on them when they need them most where their education is concerned. They have been literally excluded from decision-making and participating in the development of their country.

\section{Conclusion}

Although the geographical isolation and the great cultural distance of ethnic minority groups to the majority groups is evident and prevalent in and outside the classrooms, the Botswana national celebrations close this distance by bringing the groups together to showcase their performances. Inside the classrooms, the government decided to adopt an education policy that reverses the lives of ethnic minority groups to suit those of the major groups by assimilating them instead of promoting the multilingual and multicultural status. While research has been informing the authorities about lack of multilingualism and multiculturalism in the classrooms, the educational authorities seem not to regard the issue as an urgent matter. Bule (2015) articulated this status as such, "This is hypocrisy. It is simply a lullaby. We have leadership that concentrates on peripheral things at the expense of things that really matter to the people". Hence, this could mean that Botswana takes multilingualism and multiculturalism as a way of entertaining the public rather than making learners recognize who they are and develop and grow their potential and talent in the diverse classrooms and also contribute towards the development of their country.

The Ministry of Education and Skills Development needs to reinforce educational aspects and celebrate multilingualism and multiculturalism in classrooms, because they are a reality; they exist, and are here to stay. The Botswana language-in-education policy needs to articulate clearly how the heterogeneous classes could be taught and how their uniqueness could be celebrated within the education system. If multilingualism and multiculturalism can be celebrated in the community or at societal level, then it is possible to do so in the classrooms.

\section{References}

Arthur, J. (1997). “There must be something undiscovered which prevents us from doing our work well”: Botswana primary teachers' views on educational language policy. Language and Education, 11(4), 225-241.

Batibo, H. (2005). Language decline and death in Africa: Causes, consequences and challenges. International Journal of Bilingual Education and Bilingualism, 3(3), 149-166. 
Biseth, H. (2008). Multilingualism and education for democracy. International Review of Education, 55(1), 5-20. doi:10.1007/s11159-007-9079-3.

Bjorklund, M. (2013). Multilingualism and multiculturalism in the Swedish-medium primary school classroom in Finland-Some teachers views. International Electronic Journal of Elementary Education, 6(1), 117-136.

Bolaane, M. M., \& Saugestad, S. (2006). Mother tongue: Old debates and new initiatives in San education. Indigenous Affairs, $1(6), 46-54$.

Bule, E. (2015, March 13). Cultural festivals prioritised over mother tongue teaching. Botswana Guardian Northern Extra.

Chebanne, A. (2002). Minority languages and minority people: Issues on linguistic, cultural and ethnic death in Botswana. In I. Mazonde (Ed.), Minorities in the millennium: Perspectives from Botswana (pp. 47-56). Gaborone: Lightbooks.

Coehlo, E. (2009). Language and learning in multilingual classrooms: A practical approach. Bristol, U.K.: Multilingual Matters.

Cummins, J. (2000). Language power and pedagogy: Bilingual children in the crossfire. Cleveland, U.K.: Multilingual Matters.

Feinberg, W. (1996). The goals of multicultural education: A critical re-evaluation. In F. Margonis (Ed.), Philosophy of education. Urbana, I.L.: Philosophy of Education Society.

Gordon, M. M. (1964). Assimilation of American life: The role of race, religion and national origin. Journal of Multilingual and Multicultural Development, 11, 12.

Hays, J. (2002). Education and the San of Southern Africa: The search for alternatives. In I. Mazonde (Ed.), Minorities in the millennium: Perspectives from Botswana (pp. 73-88). Gaborone: Lightbooks.

Kukathas, C. (2004). Theories of multiculturalism. Ethical Theory and Moral Practice, 7, 215-225.

Kymlicka, W. (1995). Multicultural citizenship: A liberal theory of minority rights. Oxford, U.K.: Clarendon Press.

Le Roux, W. (1999). Torn apart: San children as change agents in a process of acculturation (A report on the educational situation of San children in Southern Africa). Shakawe: Kuru Development Trust.

Mokgwathi, T. (2011). The role of code-switching in teaching and learning selected senior secondary schools in Botswana (Unpublished Ph.D. thesis, University of Pretoria).

Mokibelo, E. B. (2014). San voices: Why we drop out of school. Australian Journal of Indigenous Education, 43(2), 185-194.

Molosiwa, A. (2005). Extinction or distinction? Empowering Setswana as the medium of instruction and instrument in Botswana schools. In B. Brock-Utne, \& R. K. Hopson (Eds.), Languages of instruction for African emancipation: Focus on postcolonial contexts and considerations. Cape Town: The Centre for Advanced Studies of African Society (CASAS).

National Commission on Education. (1977). Education for Kagisano. Gaborone: Government Printers.

Nguluka, S., \& Gunnestad, A. (2011). San children-in or out of school: Baseline study on why children drop out and how to keep them in school in the Gantsi district. Gaborone: Impression House.

Nkosana, L. (2009). The linguistic situation in Botswana and the achievement of Millennium Development Goals. The African Symposium: An Online Journal of African Educational Research Network, 9(2), 323-342.

Nyati-Ramahobo, L. (1999). The national language: A resource or a problem? The implementation of the language policy of Botswana. Gaborone: Pula Press.

Nyati-Ramahobo, L. (2000). The language situation in Botswana. Current Issues in Language Planning, 1(2), 243-300.

Pai, P. (2005). Multilingualism, multiculturalism and education: Case study of Mumbai City. In J. Cohen, K. T. McAlister, K. Rolstad, \& J. MacSwan (Eds.), Proceedings of the 4th International Symposium on Bilingualism (pp. 1794-1806). Somerville, M.A.: Cascadilla Press.

Pansiri, O. N. (2008). Improving commitment to basic education for the minorities in Botswana: A challenge for policy and practice. International Journal of Educational Development, 28, 446-459.

Polelo, M. M. (2004). Disengagement from school among the Remote Area Dweller Settlers (RADs) of Western Botswana: Conflicting cultural and value systems. Educational Research and Knowledge Systems, pp. 65-109.

Republic of Botswana. (1993). Report on the Revised National Policy on Education. Gaborone: Government Printers.

Republic of Botswana. (1994). Revised national policy on education. Gaborone: Government Printers.

Republic of Botswana. (2005). Upper primary syllabus: Curriculum development and evaluation department. Gaborone: Government Printers

Republic of Botswana. (2011). Population and housing census. Gaborone: Government Printers.

Republic of Botswana. (2012). The national cultural day speech. Gaborone: Botswana Youth, Sports and Culture.

Republic of Botswana. (2013). The national language day speech. Gaborone: Botswana Youth, Sports and Culture.

Skutnabb-Kangas, T. (1988). Multilingualism and the education of minority children. In T. Skutnabb-Kangas, \& J. Cummins (Eds.), Minority education: From shame to struggle (pp. 9-44). Avon, U.K.: Multilingual Matters. 
Skutnabb-Kangas, T. (2000). Linguistic genocide in education or worldwide diversity and human rights? London, U.K.: Lawrence Earlbaum.

Tötemeyer, A. (2009, September 2-4). Multilingualism/multiculturalism in Africa and its impact on a reading culture: the Namibian experience. In D. Lombello, \& L. Marquard (Eds.), Proceedings of the 38th Annual Conference of the International Association of School Librarianship Incorporating the 13th International Forum on Research in School Librarianship, Abano Terme, Padova, Italy. Padova: International Association of School Librarianship.

United Nations Development Program (UNDP). (2003). Human development report: Millennium Development Goals: A compact among nations to end human poverty. Oxford, U.K.: Oxford University Press.

Wolff, H. E. (2010). Multilingualism and language policies in Anglophone and Francophone Africa from a sociolinguistic macro-perspective, with reference to language-in-education issues. Paper presented at The 5th International Expert Workshop for Alumni of German-African Network of Alumni and Alumnae (GANAA), Dakar, Senegal. 